\title{
HONORARIUM
}

\section{On the award of TMS Honorary Membership, 15 November 2006 Dr John Whittaker - an appreciation}

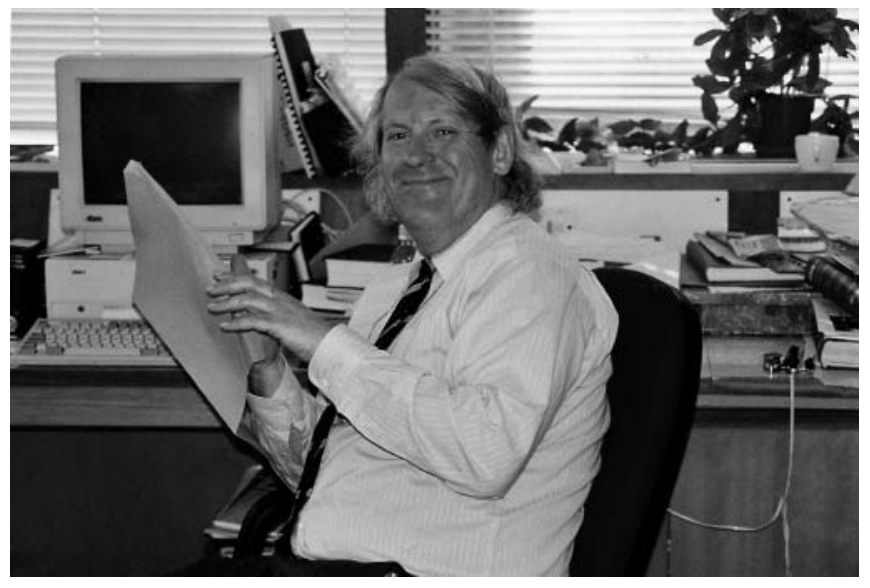

John Eustace Whittaker was born near Burnley, Lancashire on 25 September 1945 and educated at St Mary's College, Blackburn. Despite being a devoted Lancastrian, fate has decreed that since leaving school he has spent the rest of his life elsewhere and he is now a resident of south Essex. His interest in earth science was stimulated by the Geography and Geology teacher at St Mary's College, Ken James, and consequently he entered the then University College of Wales, Aberystwyth to read Joint Geography and Geology in 1964. John was, however, 'rescued' from the geographical side of things by the redoubtable Robin Whatley (TMS Honorary Member 2004) and, in 1967, commenced research under his supervision, at the same time striking up what was to become a lifelong friendship with him, and also with John Haynes. John's doctoral work concerned living ostracods of coastal sites in southern England and his thesis, 'The taxonomy, ecology and distribution of Recent brackish marine Ostracoda from localities along the coast of Hampshire and Dorset (Christchurch harbour, The Fleet and Weymouth Bay)', was a monumental two volumes submitted in 1972. From this developed Marine and Brackish Water Ostracods (Athersuch et al., 1989), an important synoptic work still in regular use (if you can find a copy). Fate again took a hand when, in 1971, a position in the Natural History Museum, London became available, working with another formidable character, the late Geoffrey Adams - on foraminifera rather than ostracods! John worked at the NHM until his retirement in 2005, and served as Head of Micropalaeontology between 1988 and 2002. In 2009, he received the prestigious Joseph A. Cushman Award of the Cushman Foundation for Foraminiferal Research, for his excellence in foraminiferal research.

Despite being employed to work with foraminifera, John has never lost his ostracod roots; and, unusually - indeed one might say unprecedentedly - has published extensively on both groups in the course of his long and distinguished academic career. He has authored or co-authored some 170 publications, at a rate of about five a year; including seven books, at a rate of one about every five years (Bronnimann \& Whittaker, 1988; Whittaker, 1988; Athersuch et al., 1989; Banner et al., 1991; BouDagherFadel et al., 1997; Whittaker et al., 1998; Whittaker \& Hart, 2009). One could scarcely legitimately accuse him of what he would call 'slackness'; rather, one should appropriately acknowledge what has undoubtedly been on his part a 'good effort'!

John published principally on ostracods in the early part of his career, from the 1970s through to the early 1980s. At this time, he published a large number of papers on his thesis material in that pioneering journal A Stereo-Atlas of Ostracod Shells (for which he was later an Editor and Treasurer for many years). He also published a number of papers on the ecology of Fleet Lagoon in Dorset, and became an active member of the Fleet Study Group. More recently, he has continued to publish on ostracods, on topics as diverse as Indian inter-Trappean assemblages, and the living 'terrestrial' taxon Terrestricythere.

In the middle part of his career, from the late 1980s to the early 1990s, John published principally on foraminifera. He had a long and fruitful collaboration with the late Paul Brönnimann, whom he describes as having been like a father to him, at this time. This collaboration resulted in a series of seminal papers on the systematics of agglutinated benthic foraminifera. The majority of John's papers on foraminifera have been on the systematics of the agglutinated benthics; the so-called 'larger' agglutinated and calcareous benthics, including the extinct Fusulinida, and the extant Rotaliida; and the planktonics or Globigerinida. It is important to note that these pure systematic papers have laid the foundation for subsequent applied palaeobiological and biostratigraphical studies, for example those on the palaeoecology of marginal marine foraminifera, and their applications in Quaternary sea-level reconstructions. It is also important to note that he has made significant personal contributions to a number of applied studies, including those on the Permian of the Far East, the Jurassic and Cretaceous of the Middle East, the 'Tertiary' of the Middle and Far East, and the Quaternary, world-wide.

John has continued to publish on both ostracods and foraminifera into the latter part of his career, from the late 1990s to the present time, albeit with a slight shift in focus toward applications in Quaternary geology and various aspects of archaeology, including archaeostratigraphy and environmental archaeology (palaeobathymetry and sea-level reconstruction, and palaeobiogeography and climate reconstruction). Even since his nominal retirement, he has remained as active as ever. He has recently started to publish extensively on the foraminiferologist and polymath Edward Heron-Allen, one of the more fascinating, not to say louche, characters ever to have inhabited the world of micropalaeontology; and has become a leading light of the Heron-Allen Society. John's own interests outside work are almost as diverse as Heron-Allen's, although less louche; and cover his family (his wife Christine, whom he met while working at the NHM, and his sons too numerous to 
enumerate), his rose garden, his stamp collection and his railway library - as he puts it himself, 'I was hooked on steam trains as a small boy and have never grown up'.

John is a stalwart of The Micropalaeontological Society, and has served the society in many ways, especially as Chair (19982001) and Treasurer (1982-1991). He is current Secretary of the Ostracod Group, and has recently been instrumental in overseeing the completion of the latest TMS Special Publication Ostracods in British Stratigraphy (Whittaker \& Hart, 2009). While invariably busy and productive scientifically, John always makes time to unselfishly help others. Indeed, in this respect he is certainly his own worst enemy, as he would be the first to admit over a bottle of wine in local restaurant 'Pierino'. I (RWJ) know I owe him a considerable debt of gratitude for all the freely offered advice and mentorship he has provided me with over the years, and I suspect that the same could be said of a generation of students and a great many visitors to the NHM.

The Micropalaeontological Society is delighted to recognize the scientific achievements and long service to the society of John Whittaker with well-deserved Honorary Membership.

\section{REFERENCES}

Athersuch, J., Horne, D.J. \& Whittaker, J.E. 1989. Marine and Brackish Water Ostracods. Linnean Society of London 'Synopses of the British Fauna' Series, No. 43 E.J. Brill, Leiden, 343 pp.

Banner, F.T., Gillmore, G.K., Highton, J. \& Whittaker, J.E. 1991. Mesozoic Foraminifera from the Middle East in the Collections of the Natural History Museum, London. The Natural History Museum, London, 335 pp.
BouDagher-Fadel, M.K., Banner, F.T. \& Whittaker, J.E. 1997. The Early Evolutionary History of Planktonic Foraminifera. Chapman \& Hall, London, xii+260pp.

Bronnimann, P. \& Whittaker, J.E. 1988. The Trochamminacea of the Discovery Reports. British Museum (Natural History), London, viii+152pp.

Whittaker, J.E. 1988. Taxonomy and Distribution of Smaller Benthic Foraminifera from Coastal Ecuador (Late Oligocene-Late Pliocene). British Museum (Natural History), London, xi+194pp.

Whittaker, J.E., Jones, R.W. \& Banner, F.T. 1998. Key Mesozoic Benthic Foraminifera of the Middle East. The Natural History Museum, London, vii+236pp.

Whittaker, J.E. \& Hart, M.B. (Eds). 2009. Ostracods in British Stratigraphy. The Micropalaeontological Society, Special Publication, The Geological Society, London, viii+485pp.

Robert W. Jones Advanced Geosciences Team, $B G$ Group PLC, 100 Thames Valley Park Drive, Reading, Berkshire RG6 1PT (e-mail: Bob.Jones@bg-group.com)

Alan R. Lord
Forschungsinstitut Senckenberg,
Senckenberganlage 25,
D-60325 Frankfurt-am-Main,
Germany
(e-mail: alan.lord@senckenberg.de)

